\title{
KONTROLOWANA LIBERALIZACJA PRAWA PRACY JAKO KONCEPCJA ROZWOJU RYNKU ZATRUDNIENIA NA PRZYKŁADZIE ZATRUDNIENIA PRACOWNIKÓW TYMCZASOWYCH PRZEZ AGENCJE PRACY TYMCZASOWEJ
}

\section{WSTĘP}

Celem artykułu jest podjęcie rozważań dotyczących wzajemnych relacji pomiędzy doktryną i judykaturą prawa pracy a oczekiwaniami przedsiębiorców dotyczących uregulowań prawnych dotyczących zatrudnienia umiejscowionych na tle szybko zmieniającego się rynku pracy i globalnej gospodarki. Poddano analizie tezę, że materialne prawo pracy powinno nie tylko stać na straży funkcji ochronnej oraz zasady uprzywilejowania pracownika, ale także wspierać i promować rozwój przedsiębiorczości tworzącej miejsca pracy.

Omówiona została rola w tym procesie nietypowych form zatrudnienia, w szczególności zatrudnienia tymczasowego w świetle uregulowań normatywnych tego zjawiska począwszy od nowelizacji Kodeksu pracy w 2002 roku umożliwiającej powstanie rynku pracy tymczasowej, poprzez uchwalenie w 2003 roku ustawy o zatrudnianiu pracowników tymczasowych, a skończywszy na omówieniu rynku pracy tymczasowej w 2014 roku.

W artykule postawiono otwarte pytania o to, jakie ma i jakie powinno mieć miejsce zatrudnienie tymczasowe w polskim prawie pracy? Czy kategoria „atypowości” jest stałym wyznacznikiem jej miejsca czy też rynek pracy i otoczenie makroekonomiczne sprawią, że „atypowość” stanie się wkrótce koniecznym standardem. Czy po-

\footnotetext{
* Doktorant, Polska Akademia Nauk w Warszawie, Instytut Nauk Prawnych.
} 
stulowane i wspierane w ustawodawstwie UE stałe zatrudnienie stoi w niedającej się rozwiązać sprzeczności wobec obiektywnych wymogów globalnej konkurencyjności i elastyczności zatrudnienia?

Choć w artykule dominuje spojrzenie na zagadnienie rozwoju pracy tymczasowej z punktu widzenia doktryny prawa pracy, to prezentowany jest ono w kontekście ekonomicznym, z uwzględnieniem nowoczesnych koncepcji organizacji i zarządzania oraz polityki rozwoju zasobów ludzkich w przedsiębiorstwach.

\section{ZASADY PRAWODAWSTWA A CELE POLITYKI TWORZENIA PRAWA}

Znana paremia prawnicza ius est ars boni et aequi oznaczająca zalecenie dla legislatorów i interpretatorów prawa czynienia tego, co dobre i słuszne znajduje zastosowanie mimo upływu 20 wieków od czasów, kiedy została sformułowana przez rzymskiego prawnika Celsusa. W czasach współczesnych zalecenie to stanowi istotną wskazówkę skierowaną do podmiotów zajmujących się polityką tworzenia prawa. Polityka ta, według powszechnie akceptowanego poglądu ${ }^{1}$, wiąże proces stanowienia prawa z jego celowością, a zatem stanowi nakaz stanowienia norm prawnych, jako swoistych środków do osiągnięcia wyznaczonych celów. Tworząc normy prawne z zamiarem oddziaływania na sprawy społeczne, prawodawca ma określony zakres swobody, co do podjęcia decyzji ustawodawczej, jego działalność jest jednak uwarunkowana czynnikami zewnętrznymi, w szczególności kontekstem politycznym, społecznym i ekonomicznym. Realizacja polityki tworzenia prawa zależy od wyboru przez ustawodawcę sposobu podejścia do środków służących jej realizacji. W wersji maksymalistycznej, podejście to charakteryzuje się spójnym działaniem zarówno co do wyboru celów prawa, jak i środków służących ich realizowaniu. Innymi słowy, prawodawca tworząc prawo, stara się racjonalnie przewidzieć następstwa wprowadzenia przepisów prawnych oraz opracować zasady, których wprowadzenie do systemu prawa wywołałoby pożądane skutki. Konkludując za L. Petrażyckim, twórcą polskiej koncepcji nauki o prawodawstwie, polityka prawa jest nauką praktyczną, która formułuje dyrektywy celowościowe wskazujące racjonalne środki prawne do osiągnięcia zamierzonych celów².

Tak pojmowane rozumienie zasady tworzenia prawa znalazło, moim zdaniem, zastosowanie w toku tworzenia norm prawnych regulujących zatrudnienie tymczasowe w polskim systemie prawa. W praktyce zastosowano, postulowany przez część doktryny i przeważającą większość środowisk gospodarczych, postulat wypracowa-

1 Por. A. Redelbach, S. Wronkowska, Z. Ziembiński, Zarys teorii państwa i prawa, Warszawa 1994, s. 166.

2 Zob. L. Petrażycki, Wstęp do nauki prawa i moralności, Warszawa 1959, s. 13. 
nia rozsądnego kompromisu łączącego potrzeby przedsiębiorstw działających na globalnym rynku pracy z ochronną funkcją prawa pracy zmierzającą do zapewnienia, na poziomie normatywnym, ochrony pracownikom, jako słabszej stronie stosunku pracy.

\section{ZATRUDNIENIE TYMCZASOWE W POLSKIM PRAWIE PRACY}

Analiza pełnego przeglądu procesu legislacyjnego dotyczącego pracy tymczasowej przekracza ramy niniejszego referatu. Warto jednak przeanalizować najważniejsze fazy tego procesu, aby zrozumieć istotę rozsądnego kompromisu legislacyjnego.

Pojawienie się w Polsce pierwszych agencji pracy tymczasowej skłaniało do poszukiwania podstaw prawnych tego rodzaju formy zatrudnienia. W początkowym okresie adaptacji zatrudnienia tymczasowego w naszym kraju, kiedy nie było żadnych przepisów regulujących tę formę zatrudnienia, występowały wątpliwości, co do legalności takiego zatrudnienia. Przepisem, który najczęściej brano pod uwagę, był art. $174^{1}$ k.p. wprowadzony ustawą nowelizacyjną z 7 kwietnia 1989 r. ${ }^{3}$ Jej celem było wsparcie pracodawców przeżywających przejściowe trudności gospodarcze i wynikającą stąd niemożność zapewnienia załodze odpowiedniego zatrudnienia. Według § 1 tego artykułu, pracodawca mógł, za zgodą pracownika wyrażoną na piśmie, udzielić mu urlopu bezpłatnego w celu wykonywania pracy u innego pracodawcy przez okres ustalony w zawartym w tej sprawie porozumieniu między pracodawcami. Pogląd uznający ten przepis za podstawę prawną zatrudnienia tymczasowego w Polsce był szeroko kwestionowany. W szczególności, gdy na rynku pracy nie funkcjonowały wtedy podmioty zajmujące się pośrednictwem pracy, a tym bardziej pracą tymczasową. Prawne funkcjonowanie niepublicznych instytucji, zajmujących się pośrednictwem pracy stało się możliwe od 1990 roku. Do tego czasu monopol na usługi z zakresu pośrednictwa pracy posiadały publiczne służby zatrudnienia. Pierwszym aktem normatywnym umożliwiającym funkcjonowanie niepublicznych biur pośrednictwa pracy, była ustawa o zatrudnieniu z 29 grudnia 1989 r. $^{4}$

Kolejnym etapem procesu legislacyjnego była nowelizacja kodeksu pracy z 24.8.2001 roku wprowadzająca nową, nieznaną do tej pory polskiemu prawu pracy, instytucję - pracy tymczasowe ${ }^{5}$. Ustawodawca usankcjonował tym samym, istniejącą na polskim rynku, praktykę funkcjonowania tzw. leasingu pracowniczego. Stosunkowo ograniczony zakres przedmiotowej regulacji sprawiał jednak, że dla

3 Ustawa z dnia 7 kwietnia 1989 roku o zmianie ustawy Kodeks pracy oraz niektórych ustaw (Dz.U. Nr 20, poz. 207) weszła w życie 1 maja 1989 roku.

4 Ustawa z dnia 29 grudnia 1989 roku o zatrudnieniu, Dz.U. Nr 75, poz. 446.

5 Ustawa z dnia 24 sierpnia 2001 roku o zmianie ustawy - Kodeks pracy oraz o zmianie niektórych innych ustaw, Dz.U. Nr 128, poz. 1405. 
pełnego określenia treści stosunków prawnych łączących podmioty pracy tymczasowej (agencji pracy tymczasowej, pracownika, podmiotu korzystającego) koniecznym było odpowiednie odwołanie się do ogólnych norm prawa pracy oraz norm cywilnoprawnych.

Konieczność pełnego usystematyzowania instytucji pracy tymczasowej doprowadziła do przygotowania rządowego projektu ustawy o zatrudnieniu pracowników tymczasowych skierowanego do łaski marszałkowskiej w dniu 12.02.2003 r. Projekt rozpatrywany był przez Komisję Nadzwyczajną do rozpatrzenia projektów ustaw związanych z programem rządowym „Przedsiębiorczość - Rozwój - Praca”. Komisja przedłożyła Sejmowi sprawozdanie ze swoich prac w czerwcu tego samego roku z rekomendacją uchwalenia ustawy bez poprawek. Ustawa weszła w życie 1 stycznia 2004 roku. Od tego czasu ustawa była nowelizowana 4-krotnie. Zmiany miały charakter bądź porządkowy, bądź zgodny z pierwotnym celem jej uchwalenia - rozsądnej liberalizacji prawa pracy.

Pierwsza nowelizacja pochodzi z roku 2004, a dotyczyła dostosowania przepisów prawa polskiego do integracji europejskiej poprzez dodanie do tytułu ustawy stosownego odnośnika.

Druga nowelizacja dotyczyła przepisów BHP w zakresie badania wypadków przy pracy i kwestii dotyczących szkoleń z zakresu BHP6.

Kolejna zmiana, która weszła w życie 1 lutego 2009 roku w odmienny od wersji pierwotnej sposób definiuje pojęcie pracodawcy użytkownika. Na mocy tej nowelizacji pracodawcą użytkownikiem jest pracodawca lub podmiot niebędący pracodawcą w rozumieniu kodeksu pracy wyznaczający pracownikowi skierowanemu przez agencję pracy tymczasowej zadania i kontrolujący ich wykonanie ${ }^{7}$. W poprzedniej wersji art. 2 pkt 1 ustawy definicja pracodawcy odwoływała się do definicji zawartej w ustawie o zatrudnieniu i przeciwdziałaniu bezrobociu.

Ostatnia zmiana ustawy była odpowiedzią na szereg postulatów pochodzących od przedsiębiorców prowadzących agencje pracy tymczasowej dotyczących uproszczenia i zliberalizowania niektórych przepisów. Dotyczyły one głównie obowiązku wydawania świadectwa pracy po każdorazowym ustaniu stosunku pracy, zakazu zatrudniania pracowników przez podmioty, które w okresie 6 miesięcy poprzedzających zatrudnienie przeprowadziły wśród swoich pracowników tzw. zwolnienia grupowe i wydłużenia okresu wykonywania pracy przez pracownika u pracodawcy użytkownika z 12 do 18 miesięcy w okresie 36 miesięcy ${ }^{8}$.

6 Ustawa z dnia 13 kwietnia 2007 roku o Państwowej Inspekcji Pracy, Dz.U. Nr 89, poz. 589.

7 Ustawa z dnia 19 grudnia 2008 roku o zmianie ustawy o pomocy zatrudnienia i instytucjach rynku pracy oraz o zmianie niektórych innych ustaw, Dz.U. z 2009 r., Nr 6, poz. 33.

8 Ustawa z 23 października 2009 roku o zmianie ustawy o zatrudnianiu pracowników tymczasowych, Dz.U. Nr 221, poz. 1737. 


\section{KOMPROMIS LEGISLACYJNY W ZATRUDNIENIU TYMCZASOWYM}

Ustawodawca polski regulując instytucję zatrudnienia tymczasowego przyjął założenie, że celem ustawy jest zmniejszenie bezrobocia, ograniczenie szarej strefy, zmniejszenie wydatków budżetowych poprzez zmniejszenie wydatków na zasiłki dla bezrobotnych oraz poprawę statusu pracowniczego osób wykonujących pracę tymczasową ${ }^{9}$.

Z tego powodu, uznając za sprzeczne z głównym celem ustawy, polski prawodawca odrzucił skrajne propozycje zarówno strony związkowej, jak również ze strony pracodawców formułowane na etapie procesu legislacyjnego a dotyczące m.in.:

1. Uzależnienia zatrudnienia pracownika tymczasowego przez pracodawcę użytkownika od niezgłoszenia sprzeciwu przez zakładową organizację związkową (postulat związkowy);

2. Nałożenia na pracodawcę użytkownika obowiązku informowania organizacji związkowej o wolnych etatach (postulat związkowy);

3. Nałożenia na pracodawcę obowiązku uzgadniania powierzenia pracy pracownikowi tymczasowemu bez względu na okres zatrudnienia (postulat związkowy);

4. Pozbawienia pracodawcy prawa zatrudniania pracowników tymczasowych do roku od przeprowadzenia zwolnień grupowych (postulat związkowy);

5. Zwolnienia agencji pracy tymczasowej od obowiązku tworzenia Funduszu Socjalnego i dokonywania odpisu na PFRON (postulat pracodawców) ${ }^{10}$.

Budowanie kompromisu wokół regulowania pracy tymczasowej odbywało się w określonym kontekście społecznym i gospodarczym. Wpisuje się w trwający od lat spór obecny zarówno w doktrynie prawa polskiego ${ }^{11}$, jak również europejskiego, a dotyczący teorii zmiany prawa pracy. Kluczowym momentem tego sporu było pojawienie się pojęcia „globalizacji”. Początkowo prawo pracy, pomimo, że było częściowo regulowane na poziomie międzynarodowym, zwłaszcza konwencjami i zaleceniami MOP, odnosiło się jednak, w przeważającej części do stosunków pracy będących pod jurysdykcją krajową. Jednak począwszy od połowy XX wieku w coraz większym zakresie zaczęły oddziaływać czynniki zewnętrzne, określane, jako globalizacja. Zgodnie z teorią zarządzania, globalizację wiąże się głównie ze zmianami w gospodarce światowej, związaną ze zwiększeniem międzynarodowej wymiany dóbr i usług, zwiększeniem przepływu bezpośrednich inwestycji zagranicznych i wzrostem międzynarodowych transakcji finansowych.

\footnotetext{
9 Zob. uzasadnienie do ustawy, www.sejm.gov.pl [dostęp: 5.11.2014].

10 Ibidem.

11 Temat ten omawiał już w poł. XX wieku; zob. S.M. Grzybowski, Wstęp do nauki prawa pracy, Warszawa 1947.
} 


\section{POLITYKA TWORZENIA PRAWA NA GLOBALNYM RYNKU PRACY}

Globalizacja gospodarki spowodowała konieczność pojawienia się również globalnego rynku pracy. Oznacza on w praktyce zmniejszenie się administracyjnych, ekonomicznych i społecznych barier przepływu pracowników między regionami oraz krajami. Pojawiło się wręcz pojęcie „rynek pracy o dużej prędkości”, na którym najważniejszym zasobem nie jest organizacyjny potencjał firmy i jej skłonność do innowacji, lecz informacje i idee pracowników.

Jedną z konsekwencji globalizacji jest porównywanie kosztów pracy w różnych krajach w celu wybrania optymalnego, często najtańszego, miejsca zatrudnienia. W coraz większej skali przedsiębiorcy, i to nie tylko korporacje międzynarodowe, ale małe i średnie firmy krajowe, mają możliwość przenoszenia produkcji i usług do państw o niższych kosztach zatrudnienia ${ }^{12}$. Rozważając pojęcie „globalne prawo pracy" należy zwrócić uwagę na globalizację regionalną. Takie sformułowanie jest najczęściej wiązane z UE. Pojawiło się ono dlatego, że europejskiej integracji regionalnej towarzyszą zjawiska właściwe globalizacji. Z jednej strony globalizacja wzmacnia niepracownicze zatrudnienie i transformację pracy najemnej ${ }^{13}$, z drugiej strony wciąż obowiązują dokumenty programowe lansujące pełne zatrudnienie. Unia Europejska w swojej strategii zatrudnienia opowiada się za przyciągnięciem na rynek pracy jak największej liczby osób i na uczynieniu pracy realną perspektywą dla wszystkich ${ }^{14}$. Zakłada też osiągnięcie pełnego zatrudnienia lepszej jakości.

Ten ekonomiczny i społeczny kontekst stanowił istotny paradygmat dla polskiego parlamentu w trakcie prac nad ustawą o zatrudnianiu pracowników tymczasowych. Z jednej strony, wzięto pod uwagę opisane powyżej względy celowościowe ustanowienia norm regulujących zatrudnienie tymczasowe, z drugiej zaś strony utrzymano istotne ograniczenia utrzymujące ochronny charakter przepisów ustawy. I tak, ograniczenia dotyczą przede wszystkim przyczyn uzasadniających zatrudnianie pracowników tymczasowych, maksymalnego okresu, w jakim pracownik tymczasowy może wykonywać pracę na rzecz jednego pracodawcy użytkownika oraz sytuacji wykorzystanie tej formy zatrudnienia. Maksymalny okres zatrudnienia pracownika tymczasowego u jednego pracodawcy w Polsce wynosi 18 miesięcy ${ }^{15}$ w okresie 36 miesięcy.

12 Zob. K. Walczak, Wpływ globalizacji ogólnoświatowego kryzysu na podstawy i warunki zatrudnienia. Wyzwania dla polskiego prawa pracy, [w:] L. Florek, Ł. Pisarczyk (red.), Wspótczesne problemy prawa pracy i ubezpieczeń społecznych, LexisNexis, Warszawa 2011, s. 83.

13 Zob. I. Boruta, W sprawie przyszłości prawa pracy, „Praca i Zabezpieczenie Społeczne” 2005, nr 4, s. 3.

14 Zob. Decyzja Rady 2003/578/WE z 22 lipca 2003 roku w sprawie wytycznych polityk zatrudnienia, Dz.Urz. UE L 197/13 z dnia 5 sierpnia 2003 roku.

15 Po nowelizacji ustawy z dnia 23 października 2009 roku o zmianie ustawy o zatrudnianiu pracowników tymczasowych (Dz.U. Nr 221, poz. 1737) weszła w życie 24.01.2010 roku. 
W przypadku zatrudnienia pracownika tymczasowego na zastępstwo za nieobecnego pracownika praca tymczasowa może być wykonywana przez 36 miesięcy. Okresy te nie różnią się zasadniczo od rozwiązań obowiązujących w innych państwach UE. Także katalog przyczyn uzasadniających wykorzystanie pracowników tymczasowych jest bardzo ogólny i w niewielkim stopniu ogranicza zastosowanie tej formy zatrudnienia w praktyce. Lista zdarzeń uniemożliwiających zatrudnienie pracowników tymczasowych nie odbiega od europejskich rozwiązań. Przykładami mogą być zakaz zastępowania pracownika strajkującego, zakaz zatrudniania pracowników pracodawcy użytkownika, jako pracowników tymczasowych u tego pracodawcy czy też zakaz wykorzystania pracowników tymczasowych do wykonywania prac szczególnie niebezpiecznych.

Polski prawodawca, konsekwentnie realizując główny cel ustawy, zadbał o spójność podejścia do celu ustawy i nie wprowadził szczególnych wymogów dotyczących uzyskania statusu agencji pracy tymczasowej. W porównaniu z analizowanymi regulacjami prawnymi innych państw UE można przyjąć, iż przepisy te mają typowy charakter i analizowane całościowo nie odbiegają w sposób znaczący od rozwiązań innych państw UE ${ }^{16}$.

\section{PODSUMOWANIE}

Tytułem podsumowania warto przytoczyć dane statystyczne obrazujące efekty omawianego w niniejszym referacie rozsądnego kompromisu legislacyjnego ${ }^{17}$. W okresie 10 lat działalności agencji pracy tymczasowej w Polsce ich liczba zwiększyła się z 384 w 2003 roku do 4536 w roku 2013. Polska jest na pierwszym miejscu w Europie w rocznej dynamice wzrostu zatrudnienia tymczasowego, które przekracza $19 \%$ przy średniej dla UE na poziomie 1,4\% ${ }^{18}$. Udział pracowników tymczasowych w stosunku do ogółu zatrudnionych wynosi w Polsce 1\%, a warto podkreślić ewidentną korelację między tym wskaźnikiem a elastycznością rynku pracy i poziomem bezrobocia. W krajach, gdzie bezrobocie jest najniższe wskaźnik udziału zatrudnienia tymczasowego jest najwyższy (Wielka Brytania 3,8\%, Holandia 2,7\%, Luxemburg $2,4 \%$, Niemcy $2,2 \%$,), tymczasem w krajach o największej stagnacji zatrudnienia wskaźnik ten nie przekracza 1\% (Włochy 0,9\%, Hiszpania 0,5\% czy Grecja 0,2\%).

Według danych opublikowanych przez Międzynarodową Konfederację Prywatnych Agencji Zatrudnienia we współpracy z Boston Consulting Group ${ }^{19} 74 \%$ firm

16 Por. G. Orłowski, Rygorystycznie nie znaczy skutecznie. Regulacje prawne pracy tymczasowej w Polsce i w innych krajach UE, „Personel i Zarządzanie” 2004, nr 6, s. 24.

17 Zob. Rynek agencji zatrudnienia 2013,. www.polskieforumhr.pl [dostęp: 5.11.2014].

18 Wzrost w USA w tym samym okresie wyniósł 6,9\%, natomiast w Japonii $26 \%$.

19 Economic Report CIETT, www.polskieforumhr.pl [dostęp: 5.11.2014]. 
korzystających obecnie z zatrudnienia tymczasowego z wykorzystaniem agencji pracy tymczasowej nie zatrudniłoby tych samych pracowników na podstawie typowej umowy o pracę. Ponadto, według tych samych danych, $62 \%$ obecnych miejsc pracy stworzonych w agencjach pracy tymczasowej nie powstałoby w ogóle, gdyby nie byłoby takie możliwości prawnej w formie zatrudnienia tymczasowego. To oznacza, że spośród wszystkich 509000 pracowników tymczasowych zatrudnionych obecnie w Polsce 300 tys. osób, reprezentujących często obie najbardziej wykluczone grupy zawodowe obejmujące pracowników poniżej 25 roku życia oraz powyżej 50 roku życia, nie miałoby szans na zatrudnienie.

Praca tymczasowa oczywiście nie jest i nie może być jedynym panaceum dla polityki zatrudnienia państwa. Może być natomiast przykładem na to, w jaki sposób należy realizować skuteczną i racjonalną politykę tworzenia prawa.

\section{BIBLIOGRAFIA}

Boruta I., W sprawie przyszłości prawa pracy, „Praca i Zabezpieczenie Społeczne” 2005, nr 4. Florek L., Pisarczyk Ł. (red.), Współczesne problemy prawa pracy i ubezpieczeń społecznych, LexisNexis, Warszawa 2011.

Grzybowski S. M, Wstęp do nauki prawa pracy, Warszawa 1947.

Orłowski G., Rygorystycznie nie znaczy skutecznie. Regulacje prawne pracy tymczasowej w Polsce i w innych krajach UE, „Personel i Zarządzanie” 2006, nr 6.

Petrażycki L., Wstęp do nauki prawa i moralności, Warszawa 1959.

Redelbach A., Wronkowska S., Ziembiński Z., Zarys teorii państwa i prawa, Warszawa 1994.

\section{Źródła internetowe}

Economic Report CIETT, www.polskieforumhr.pl

Rynek agencji zatrudnienia 2013, www.polskieforumhr.pl

Uzasadnienie do ustawy z dnia 23 października 2009 roku o zmianie ustawy o zatrudnianiu pracowników tymczasowych, www.sejm.gov.pl

\section{Akty prawne}

Decyzja Rady 2003/578/WE z 22 lipca 2003 roku w sprawie wytycznych polityk zatrudnienia, Dz.Urz. UE L 197/13 z dnia 5 sierpnia 2003 roku.

Ustawa z dnia 13 kwietnia 2007 roku o Państwowej Inspekcji Pracy, Dz.U. Nr 89, poz. 589 ze zm.

Ustawa z dnia 19 grudnia 2008 roku o zmianie ustawy o pomocy zatrudnienia i instytucjach rynku pracy oraz o zmianie niektórych innych ustaw, Dz.U. z 2009 r., Nr 6, poz. 33.

Ustawa z dnia 23 października 2009 roku o zmianie ustawy o zatrudnianiu pracowników tymczasowych, Dz.U. Nr 221, poz. 1737.

Ustawa z dnia 24 sierpnia 2001 roku o zmianie ustawy - Kodeks pracy oraz o zmianie niektórych innych ustaw, Dz.U. Nr 128, poz. 1405.

Ustawa z dnia 29 grudnia 1989 roku o zatrudnieniu, Dz.U. Nr 75, poz. 446 ze zm.

Ustawa z dnia 7 kwietnia 1989 roku o zmianie ustawy Kodeks pracy oraz niektórych ustaw, Dz.U. Nr 20, poz. 207. 